\title{
The importance of ISO management system standards in a scenario of profound changes caused by the Covid-19 pandemic to Brazilian companies
}

\author{
Rosley Anholon * (D), Milena Pavan Serafim² (D), Thais Dibbern ${ }^{3}$ (D), Walter Leal Filho ${ }^{4,5}$ (D) \\ ${ }^{1}$ School of Mechanical Engineering, University of Campinas, Campinas, SP, Brazil. \\ ${ }^{2}$ Laboratory of Public Sector Studies, School of Applied Sciences, University of Campinas, Limeira, SP, Brazil. \\ ${ }^{3}$ Institute of Geosciences, University of Campinas, Limeira, SP, Brazil. \\ ${ }^{4}$ European School of Sustainability Science and Research, Hamburg University of Applied Sciences, Hamburg, Germany. \\ ${ }^{5}$ Department of Natural Sciences, Manchester Metropolitan University, Manchester, UK.
}

How to cite: Anholon, R., Serafim, M.P., Dibbern, T. et al. (2022), "The importance of ISO management system standards in a scenario of profound changes caused by the Covid-19 pandemic to Brazilian companies", Brazilian Journal of Operations \& Production Management, Vol. 19, No. 01, e20221248.

https://doi.org/10.14488/BJOPM.2021.042

\begin{abstract}
Goal: The aim of this viewpoint is characterized by emphasizing the importance of the management standards of the International Organization for Standardization as an information base for improvements to Brazilian managers in a scenario of profound changes caused by the Covid-19 pandemic.

Design / Methodology / Approach: Initially, a brief bibliographic research was carried out to base some information presented in the text. Later, the authors of this viewpoint discussed their ideas and established the reflections presented here, many of them based on their experiences and the Brazilian context. Finally, the final considerations were established.

Results: The main reflections are directed in the sense that most Brazilian companies have felt harshly the consequences of the economic crisis resulting from the pandemic of Covid-19 and, in some way, they need to rethink some of their administrative practices. In this scenario of profound organizational changes, we believe that the management standards of the International Organization for Standardization can be characterized as an important knowledge base, since they present information of high credibility, widely debated by experts and that are easily accessible to Brazilian managers in different themes.

Limitations of the investigation: Since it is a viewpoint, part of the information presented here are the perceptions and considerations of the authors.

Practical implications: This viewpoint shows that the standards of the International Organization for Standardization can be used as an important tool for management systems focused on innovation and employee skills management.

Originality / Value: We hope with this viewpoint to advocate for ISO management standards as important instruments of continuous improvement in a scenario of many organizational changes for Brazilian companies.
\end{abstract}

Keywords: Management; Covid-19; Brazilian Companies; ISO Management Standards.

Financial support: Conselho Nacional de Desenvolvimento Científico e Tecnológico (CNPq Productivity Grant - 307536/2018-1); and Coordenação de Aperfeiçoamento de Pessoal de Nível Superior (CAPES) (Grant - 88887.339816/2019-00)

Conflict of interest: The authors have no conflict of interest to declare.

Corresponding author: rosley@unicamp.br

Received: 28 May 2021.

Accepted: 05 June 2021.

Editor: Julio Vieira Neto and Syed Abdul Rehman Khan. 


\section{INTRODUCTION}

Covid-19 has brought significant changes to the world (Davison, 2020; Evans, 2020; Janjua et al., 2021). Almost fifteen months after the beginning of the pandemic and, even with the advance of vaccination in some regions of the planet, it is noted that the world dynamics are still far from returning to pre-Covid-19 reality. Many countries continue to adopt restrictive measures and in some of them contamination and death rates remain very high (Johns Hopkins University and Medicine, 2021). Given this scenario, companies, when possible, continue to adopt the remote work modality, establishing contact with their customers in a virtual way, among other measures.

As pointed out by Anholon et al. (2021), the Covid-19 pandemic abruptly required significant changes on the part of companies and evidenced early on that many managers neglected in the daily routine of their important administrative actions practices and concepts already well established by the academy, such as risk management, the adoption of an innovation management system, the adoption of resilience and responsiveness practices in the supply chain, the need to periodically review business plans to verify that products or services continue to add value to customers, among other issues. It cannot be said that currently in Brazil, the turbulence caused by the covid-19 pandemic has passed (Brasil, 2021), far from it, but managers need to start looking for the knowledge gaps they lack to make their companies a little more robust and modern in terms of management.

In this viewpoint, we want to establish some reflections on how the management standards of the International Organization for Standardization can be characterized as an important information base for Brazilian managers; information that is highly credible, widely debated by experts and that is easily accessible in different topics.

\section{REFLECTIONS}

A first point that we want to make clear at first in our reflections is in relation to the term "Brazilian companies". When we refer to this term, we mention most Brazilian companies that have many points to be improved in their management practices (and that were even more evident with the Covid-19 pandemic). We logically recognize that there are Brazilian organizations at the level of organizational excellence, being possible to cite examples of them in different sectors. Embraer, for example, cited by Anholon et al. (2016), can be considered a company with an excellent level of organizational practices in the aerospace sector. Other examples of companies can be found in the list published annually by the National Quality Foundation (FNQ, 2021). As commented by Schumpeter $(2015$, p. 1) in an article for "The Economist", however, the Brazilian market can in some way be understood as a "Belindia", in which there is an island of companies characterized by excellence in management (this island the size of Belgium) surrounded by a sea of companies as wide possibilities for improvement (east sea the size of India). Even though it is a six-year article, the Covid-19 pandemic showed that there is still much truth in this concept.

Faced with the need to improve the day-to-day management of the companies in which they operate, in a scenario marked by strong changes resulting from the Covid-19 pandemic, many Brazilian managers wonder where to start. We want to advocate in this viewpoint in favor of the management standards of the International Organization for Standardization, because we believe that they are characterized as important tools to guide Brazilian managers to improve their administrative activities. We view standards as a set of well-structured, pragmatic, and accessible language information. Although we mention some examples of standards, our intention is to mention the set of management standards. Remembering that the entire structuring of a standard is due to a long process with multiple stages of critical analysis and debates in which experts from different areas participate, so the final version always presents consensus information, aiming to meet different stakeholders and high credibility (International Organization for Standardization, 2021).

In relation to many Brazilian managers, even in 2021, it is still necessary to break some paradigms, especially the following: 1 ) the standards will "constrain" the daily activities of the 
company and 2) the standards are only focused on "certification". Standards do not "cast" administrative practices because they do not say how practices should be conducted; they recommend that a given action is important for a greater goal and it is up to the manager and his team to find the appropriate and pragmatic way to add value. Many Brazilian managers still need to understand this. Regarding certification, some ISO standards are plausible for certification and others are not. Even if a standard is plausible for certification, ISO does not require the manager to deploy it completely and even request its certification. The standard can be used simply as a guide, whether for discussions between the team, framework for ideas or critical analysis, etc.

As an example of what we previously advocated, we will explore a little more the ISO 56002:2020 standards and the ISO 10015:2020 standard, since the Covid-19 pandemic has highlighted the need for many Brazilian companies to have management systems focused on innovation and employee skills management (many other examples can be cited, but we will focus on these two). The importance of innovation management for companies is highlighted by (J-Figueiredo et al., 2017; Lopes et al., 2016) and supported by skills management (Martin et al., 2021; Stepanenko and Kashevnik, 2017).

A Brazilian manager who does not know where to start working on innovation issues, when studying in full the ISO 56002:2020 standard, will understand, first, what is an innovation management system and, later, understand the elements that the International Organization for Standardization considers interesting for the composition of such a system. Throughout the reading of the standard, will go through the idea that it is necessary to understand the expectations of the company's stakeholders to innovate properly, will become aware of the importance of leadership, cultural issues, focus on value realization, will understand that it is necessary to have a strategy for innovation and assignment of roles and responsibilities, among other issues. You will also understand a little better what is a process of innovation, from the identification of opportunity, through the creation and validation of the concept, the development and implementation of solutions (International Organization for Standardization, 2020a). In addition, it will be in contact with elements on the need to evaluate innovation performance and seek continuous improvement (International Organization for Standardization, 2020a).

The same can be done by managers interested in competency management elements, now in the light of ISO 10015:2020. Throughout the reading of the standard, the manager will go through elements that highlight the need to think about how external and internal factors affect the management of competencies, whether it is necessary the development of individual competencies, as a team, or both, will be aware of the importance of having processes to evaluate current levels of existing competencies and program aimed at training , may reflect on future skills needs and people development among other aspects (International Organization for Standardization, 2020b).

In both cases mentioned, or for any other ISO management standard, we believe that even if the manager does not want to implement the management system in the format presented there, reading alone already provides an interesting knowledge, which will greatly contribute to the improvements of management activities.

\section{FINAL CONSIDERATIONS}

In this viewpoint we argue that although there are Brazilian companies with management systems with practices at the level of excellence, most organizations operating in our country still neglect many of the concepts presented by Anholon et al. (2021) and these were even more marked with the Covid-19 pandemic. Innovation and management of employee skills are examples that can be easily mentioned. We go beyond and advocate in favor of ISO management standards as important tools that guide Brazilian managers in a scenario of many organizational changes in which adjustments in administrative practices become necessary so that companies can continue their business.

It is necessary to break old paradigms defended by many managers in relation to management standards and that they become seen as a set of synergistic information for 
different purposes, of high added value, as high credibility, and easy access to Brazilian managers. It is also necessary to understand that standards can be used for different purposes, such as guides for discussions between the team, framework for ideas or critical analysis, implementation or simply for knowledge acquisition.

\section{REFERENCES}

International Organization for Standardization - ISO (2020a), ISO 56002: Innovation Management - Innovation Management System - Guidelines, Geneva, Switzerland, ISO.

International Organization for Standardization - ISO (2020b), ISO 10015: Quality Management - Guidelines for competency management and people development, Geneva, Switzerland, ISO.

Anholon, R., Quelhas, O.L.G., Leal Filho, W. et al. (2016), "Assessing corporate social responsibility concepts used by a Brazilian manufacturer of airplanes: A case study at Embraer", Journal of Cleaner Production, Elsevier, Vol. 135, pp. 740-9. http://dx.doi.org/10.1016/j.jclepro.2016.06.169.

Anholon, R., Silva, D., Souza Pinto, J., Rampasso, I.S., Domingos, M.L.C. and Dias, J.H.O. (2021), “COVID-19 and the administrative concepts neglected: reflections for leaders to enhance organizational development", Kybernetes, Vol. 50, No. 5, pp. 1654-60. https://doi.org/10.1108/K-10-2020-0707.

Brasil, Ministério da Saúde (2021), "Coronavírus Panel”, available at: https://covid.saude.gov.br/ (accessed 25 May 2021).

Davison, R.M. (2020), "The transformative potential of disruptions: a viewpoint", International Journal of Information Management, Vol. 55, pp. 102149. http://dx.doi.org/10.1016/j.jijfomgt.2020.102149. PMid:32836628.

Evans, C. (2020), "The coronavirus crisis and the technology sector", Business Economics, Vol. 55 No. 4, pp. 253-66.

Fundação Nacional da Qualidade - FNQ (2021), "Best in Management - 1992-2020", available at: https://fnq.org.br/empresas-reconhecidas-em-gestao-meg-e-pnq-de-1992-a-2020/ (accessed 23 May 2021).

International Organization for Standardization - ISO (2021), "Developing Standards", available at: https://www.iso.org/developing-standards.html (accessed 25 May 2021).

J-Figueiredo, R., Ferreira, J.J., Lima, G. and Vieira Neto, J. (2017), "Innovative capacity dynamics: KIBS dimensions", Brazilian Journal of Operations \& Production Management, Vol. 14, No. 4, pp. 438-445. http://dx.doi.org/10.14488/BJOPM.2017.v14.n4.a1.

Janjua, L.R., Muhammad, F., Sukjai, P. et al. (2021), "Impact of COVID-19 pandemic on logistics performance, economic growth and tourism industry of Thailand: an empirical forecasting using ARIMA", Brazilian Journal of Operations \& Production Management, Vol. 18, No. 2, pp. e2021999. http://dx.doi.org/10.14488/BJOPM.2021.001.

Johns Hopkins University and Medicine (2021), "Coronavirus resource center", available at: https://coronavirus.jhu.edu/map.html (accessed 25 May 2021).

Lopes, A.P.V.B.V., Kissimoto, K.O., Salerno, M.S. et al. (2016), "Innovation management: A systematic literature analysis of the innovation management evolution", Brazilian Journal of Operations \& Production Management, Vol. 13, No. 1, pp. 16-30. http://dx.doi.org/10.14488/BJOPM.2016.v13.n1.a2.

Martin, J., Elg, M., Gremyr, I. et al. (2021), “Towards a quality management competence framework: exploring needed competencies in quality management", Total Quality Management \& Business Excellence, Vol. 32, No. 3-4, pp. 359-78. http://dx.doi.org/10.1080/14783363.2019.1576516.

Schumpeter. (2015), "Brazil Business Belindia: Why the country produces fewer world-class companies than it should", The Economist, 26 February.

Stepanenko, V. and Kashevnik, A. (2017), "Competence management systems in organisations: A literature review", in Proceeding of the 20th Conference of Fruct Association, IEEE, St. Petersburg, Russia. http://dx.doi.org/10.23919/FRUCT.2017.8071344.

Author contributions: All the authors contributed equally to this viewpoint. 